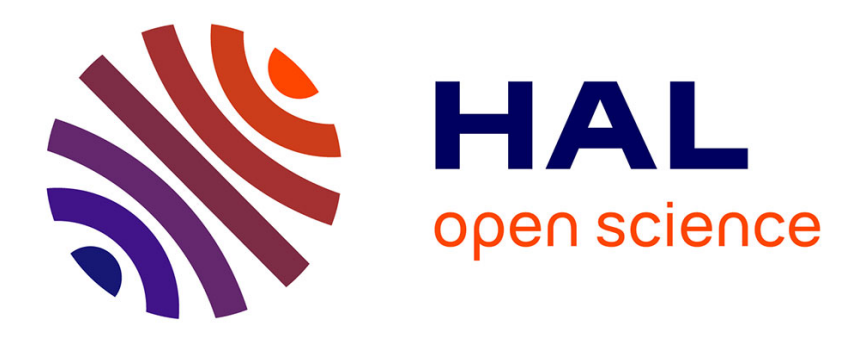

\title{
Iron and zinc biofortification strategies in dicot plants by intercropping with gramineous species. A review
}

\author{
Y. Zuo, F. Zhang
}

\section{To cite this version:}

Y. Zuo, F. Zhang. Iron and zinc biofortification strategies in dicot plants by intercropping with gramineous species. A review. Agronomy for Sustainable Development, 2009, 29 (1), pp.63-71. hal00886491

\section{HAL Id: hal-00886491 \\ https://hal.science/hal-00886491}

Submitted on 1 Jan 2009

HAL is a multi-disciplinary open access archive for the deposit and dissemination of scientific research documents, whether they are published or not. The documents may come from teaching and research institutions in France or abroad, or from public or private research centers.
L'archive ouverte pluridisciplinaire HAL, est destinée au dépôt et à la diffusion de documents scientifiques de niveau recherche, publiés ou non, émanant des établissements d'enseignement et de recherche français ou étrangers, des laboratoires publics ou privés. 


\title{
Review article
}

\section{Iron and zinc biofortification strategies in dicot plants by intercropping with gramineous species. A review}

\author{
Y. ZUO, F. ZHANG* \\ College of Resources and Environmental Sciences, China Agricultural University, Key Laboratory of Plant Nutrition and Nutrient Cycling, MOA, \\ Key Laboratory of Plant-Soil Interactions, MOE, Beijing 100094, China
}

(Accepted 3 October 2008)

\begin{abstract}
The lack of micronutrients such as iron and zinc is a widespread nutrition and health problem in developing countries. Biofortification is the process of enriching the nutrient content of staple crops. Biofortification provides a sustainable solution to iron and zinc deficiency in food around the world. Reports have highlighted the current strategies for the biofortification of crops, including mineral fertilization, conventional breeding and transgenic approaches. Any approach which could increase root growth and result in a high transfer of Fe and Zn from the soil to the plant is crucial for biofortification. In addition to these approaches, we draw attention to another important aspect of Fe and $\mathrm{Zn}$ biofortification: intercropping between dicots and gramineous species. Intercropping, in which at least two crop species are grown on the same plot of land simultaneously, can improve utilization of resources while significantly enhancing crop productivity, whereas monocropping is a traditional cropping system of only one crop growth. Monocropping has maintained crop productivity through heavy chemical inputs including the application of fertilizers and pesticides. Monocropping has therefore resulted in substantial eutrophication, environmental pollution, a food security crisis and economic burdens on farmers. Monocropping has also reduced the plant and microorganism diversity in the ecosystem. Compared with monocropped plants, intercropped plants can use nutrients, water and light better due to the spatial and temporal differences in the growth factors and a variety of species-specific mechanisms of physiological response to environmental stress. Intercropping is common in developing countries such as China, India, Southeast Asia, Latin America and Africa. In particular, interspecific interaction facilitates the iron and zinc nutrition of intercropping systems such as peanut/maize, wheat/chickpea and guava/sorghum or maize. Intercropping also increases iron and zinc content in the seeds. In a peanut/maize case study, the Fe concentrations in peanut shoots and seed were 1.47-2.28 and 1.43 times higher than those of peanut in monocropping, respectively. In intercropping of chickpea and wheat, the Fe contents in wheat and chickpea seed were increased 1.26 and 1.21 times, respectively, and $\mathrm{Zn}$ concentration in chickpea seed was 2.82 times higher than that in monocropping. In this review, we focus on exemplary cases of dicot/gramineous species intercropping that result in improved iron and zinc nutrition of the plants. We present the current understanding of the mechanisms of improvement of iron and zinc in intercropping. The available literature shows that a reasonable intercropping system of nutrient-efficient species could prevent or mitigate iron and zinc deficiency of plants. Here, we propose that intercropping can potentially offer an effective and sustainable pathway to iron and zinc biofortification.
\end{abstract}

intercropping / biofortification / iron and zinc / dicots / gramineous species

\section{INTRODUCTION}

The World Health Organization states that the lack of micronutrients such as iron and zinc represents a major threat to the health and development of populations in the world. Two billion people are anemic, many due to iron deficiency (WHO, 2007). Billions of individuals are also at risk for zinc deficiency (Prasad, 2003). Although food supplementation or fortification efforts have been effective in some countries, their overall success remains limited in developing countries. Biofortification, the process of enriching the nutrient content of crops as they grow, provides a sustainable solution to malnutrition in the world (Jeong and Guerinot, 2008). Biofortification can be achieved by utilizing crop and soil management

* Corresponding author: zhangfs@cau.edu.cn with plant breeding to increase micronutrient concentrations in the edible parts of crops. The concept of biofortification is attractive not only for improving the growing conditions of crops but also for exploiting a plant's potential for micronutrient mobilization and utilization. There have been several recent reviews on the current strategies for the biofortification of crops, including mineral fertilization, conventional breeding and transgenic approaches (Zhu et al., 2007; Mayer et al., 2008). In addition to these approaches, we would like to draw attention to another important aspect of $\mathrm{Fe}$ and $\mathrm{Zn}$ biofortification: intercropping between dicots and gramineous species, which are strategy I and Strategy II plants, respectively, in their response to iron deficiency. Relatively little attention has been paid to the effects of intercropping on crop micronutrient status. However, considering the importance of intercropping 
systems in nutrient acquisition and crop production processes, the management of intercropping would be the key to Fe and Zn biofortification.

Intercropping, which is the intermingled growth of two or more crops, is practiced in $>28$ million hectares of annually sown area in China (Liu, 1994) and is also common in other parts of the world, such as India, Southeast Asia, Latin America and Africa (Vandermeer, 1989). Multiple cropping, i.e. intercropping or intercropped cropping, plays an important role in agriculture because of the effective utilization of resources, significantly enhancing crop productivity compared with that of monocultured crops (Li et al., 1999, 2007). Facilitative root interactions in mixed cropping systems are most likely of importance for the nutritional improvement of crops grown in nutrient-poor soils and low-input agroecosystems (Zhang and Li, 2003; Li et al., 2004). Recently, some research groups have reported that interspecific root interactions and rhizosphere effects could be linked to improved Fe and $\mathrm{Zn}$ nutrient uptake in dicot plants by intercropping with graminaceous species in pairings which included maize/peanut, guava/sorghum or maize and chickpea/wheat. For instance, maize/peanut intercropping was shown to improve $\mathrm{Fe}$ and Zinc nutrition of peanut (Kamal et al., 2000; Zuo et al., 2000; Gunes et al., 2007; Inal et al., 2007). In particular, as one of the important staple crops with high consumption, any increase in mineral nutrient content might have a significant effect on human nutrition (Graham et al., 1998; Graham and Welch, 2001; Cakmak, 2002). Presumably, if the nutritional quality of such staple crops can be improved by intercropping it would benefit human nutrition, particularly for the important micronutrients iron and zinc.

In this article, we concentrate on reviewing the literature on how intercropping dicots and gramineous species has been applied to advancing our knowledge specifically related to iron and zinc improvement in plants, and speculate on its future potential impact on biofortification. Hopefully, it will provide a significant component of integrated approaches, which include conventional plant breeding, transgenic approaches and mineral fertilization. The combined use of multiple strategies for iron and zinc improvement will offer a more effective and sustainable pathway to alleviating micronutrient malnutrition.

\section{IMPROVEMENT OF FE AND ZN UPTAKE BY INTERCROPPING}

\subsection{Improvement of $\mathrm{Fe}$ and $\mathrm{Zn}$ uptake in peanut by rhizosphere effects from maize in intercropping}

Iron deficiency is a common nutritional disorder in crop plants in China, particularly in northern China where aerobic and calcareous soils are widespread. Peanut (Arachis hypogaea $\mathrm{L}$.) is the major oilseed crop in China, accounting for $30 \%$ of the total oilseed production in the country. Iron chlorosis is one of the most common yield-limiting nutrient problems in peanut grown in monocropping systems in the calcareous soils of northern China (Zuo et al., 2000). In about 50\% of these soils, the DTPA-extractable Fe concentration is lower

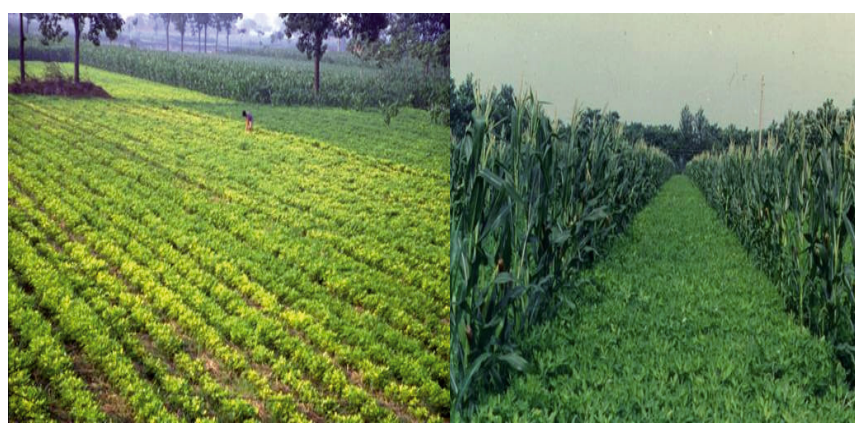

A

B

Figure 1. Peanut growing in monoculture in the field with symptoms of Fe deficiency chlorosis (A), Peanut intercropped with maize in the field without symptom of Fe deficiency chlorosis in particular in the vicinity of maize (B).

Table I. The effects of peanut intercropped with maize plants on $\mathrm{Fe}$ and $\mathrm{Zn}$ contents $\left(\mathrm{mg} \mathrm{kg}^{-1}\right.$.DW) in the shoot of peanut at the flowering stage in the field.

\begin{tabular}{lccc}
\hline Cropping systems & $\begin{array}{l}\text { Distance from } \\
\text { maize (Rows) }\end{array}$ & Fe & $\mathrm{Zn}$ \\
\hline Monocropping peanut & & $205.8 \pm 23.3^{\mathrm{c}}$ & $43.6 \pm 5.2^{\mathrm{b}}$ \\
Peanut/maize (danyu13) & 1 & $302.6 \pm 21.4^{\mathrm{a}}$ & $54.8 \pm 5.3^{\mathrm{ab}}$ \\
& 2 & $290.0 \pm 29.3^{\mathrm{a}}$ & $52.1 \pm 6.1^{\mathrm{b}}$ \\
& 3 & $279.8 \pm 40.2^{\mathrm{a}}$ & $50.6 \pm 4.2^{\mathrm{b}}$ \\
\hline
\end{tabular}

Columns with the same letter are not significantly different at 0.05 , using the LSD multiple range test.

than $5.5 \mathrm{mg} \mathrm{kg}^{-1}$ (DTPA: diethylenetriaminepentaacetic acid). For example, in most parts of Henan province iron chlorosis is very severe in peanut grown in monocropping systems in calcareous soil. (Fig. 1A). Calcareous soils are characterized by low organic matter, high $\mathrm{pH}(7.5-8.5)$ and high levels of bicarbonate. Soil amendment and foliar application of $\mathrm{Fe}$ fertilizers are usually ineffective or uneconomic measures for correction of Fe deficiency chlorosis. There is therefore considerable interest in devising practical approaches for the correction or avoidance of Fe deficiency in crops in Chinese agriculture. Chlorosis in peanut was much less pronounced when this species was intercropped with maize. This is a much more common cropping system than peanut monoculture in the region (Fig. 1B). The extent of improvement in the Fe nutritional status of intercropped peanut was found to be closely related to the distance between the peanut plants and the neighboring maize plants. The nearer the peanut plants to the maize, the less Fe chlorosis in peanut plants was observed. The severity of iron deficiency chlorosis in young leaves of peanut in the intercropping systems was closely related to the distance of the peanut plants from the maize roots when treatments were assessed during the peanut flowering period. In the unrestricted intercropping treatment, where neighboring roots of peanut and maize intermingled freely, the young leaves of peanut plants in rows 1 to 3 from the maize grew without visible symptoms of iron deficiency (Tab. I), while those in 


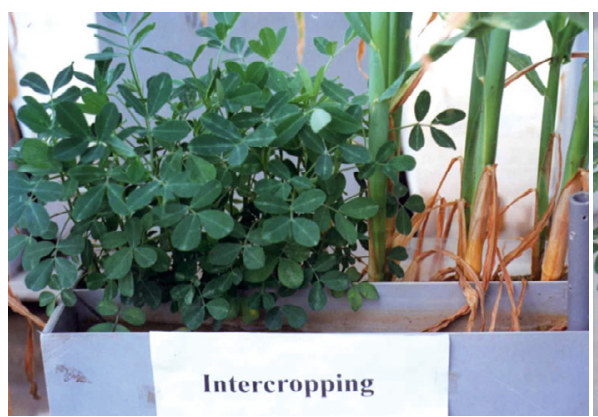

A

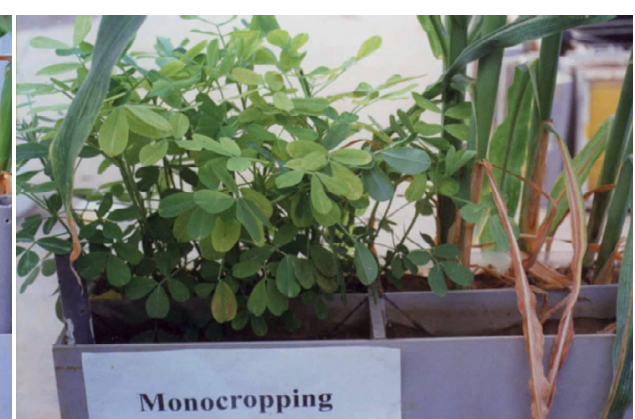

B

Figure 2. Peanut grown in intercropping with root interaction of maize and peanut without symptom of Fe deficiency chlorosis (A). Peanut grown in monocropping without root interaction of maize and peanut with symptom of Fe deficiency chlorosis (B).

rows 5 to 10 showed variable degrees of chlorosis. These results indicated that the comprehensive rhizosphere effects of maize played an important role in the improvement of the $\mathrm{Fe}$ nutritional status of peanut intercropped with maize under field conditions.

Based on the phenomena and evidence from the field, a greenhouse experiment was designed to test whether interaction between roots of maize and peanut has any effect on the $\mathrm{Fe}$ nutritional status of peanut in rhizoboxes. The only difference between the monocropping and intercropping systems in the rhizobox experiment was due to separation versus interaction between maize and peanut roots. The taller maize plants would have shaded the peanuts in both treatments, with or without root barriers, but chlorosis developed only in the former treatment. Since the peanut plants in both the monocropping and intercropping systems shared the same lighting conditions, it seems unlikely that the major interaction between the two species in rhizoboxes can be explained by a shading effect. The younger leaves of peanut plants remained green when the roots of maize and peanut interacted in the intercropping system (Fig. 2A), whereas chlorosis appeared on the youngest leaves when root interaction between the two species was prevented using a PVC barrier in the monocropping system (Fig. 2B). This indicates that maize could markedly improve the Fe nutrition of peanut plants. A more likely explanation for enhanced $\mathrm{Fe}$ nutrition was root interaction between maize and peanut. The Fe concentrations in various parts of peanut plants whose roots were allowed to mix with those of maize were generally higher than those whose roots were kept separate (Tab. II). The Fe concentration in roots, shoots and seeds of peanut plants grown in the intercropping system without root barriers were 1.3, 2.3 and 1.4 times higher, respectively, than those of peanut plants grown with root barriers (Tab. II). The chlorophyll concentration increased about threefold and the $\mathrm{HCl}$-extractable $\mathrm{Fe}$ concentration doubled in the intercropping system (Zuo et al., 2000).

It was noteworthy that the maize not only improved the $\mathrm{Fe}$ status of peanut in the intercropping system, but intercropping also enhanced $\mathrm{Zn}$ content in the peanut (Tab. II): this indicates that agronomic intercropping helps mobilize and uptake the
Table II. The effects of intercropping peanut with maize on Fe and $\mathrm{Zn}$ concentrations in peanut $\left(\mathrm{mg} \mathrm{kg}^{-1} \mathrm{DW}\right)$ grown on calcareous soil.

\begin{tabular}{|c|c|c|c|}
\hline Plant tissue & Monocropping & Intercropping & References \\
\hline & \multicolumn{2}{|c|}{$\mathrm{Fe}$} & Zuo et al., 2000 \\
\hline Shoots & $28.0 \pm 7.0^{\mathrm{b}}$ & $65.5 \pm 8.9^{\mathrm{a}}$ & \\
\hline Roots & $159.5 \pm 13.1^{\mathrm{b}}$ & $203.1 \pm 16.8^{a}$ & \\
\hline \multirow[t]{2}{*}{ Seeds } & $22.2 \pm 2.9^{\mathrm{b}}$ & $31.8 \pm 3.9^{\mathrm{a}}$ & \\
\hline & \multicolumn{2}{|c|}{$\mathrm{Zn}$} & Inal et al., 2007 \\
\hline Shoot & 10.4 & 26.2 & \\
\hline $\begin{array}{l}\text { F values } \\
*: P<0.05\end{array}$ & \multicolumn{2}{|c|}{$14.01 *$} & \\
\hline
\end{tabular}

All data were analyzed using SAS software, expressed as means of three replicates with standard deviation, and the means were subjected to another test by using the least significant difference (LSD) method at the $5 \%$ probability level (Zuo et al., 2000). Statistical significance of difference was determined by analysis of variance (ANOVA) and the LSD test at $P \leqslant 0.05$ for multiple comparisons (Inal et al., 2007).

limiting nutrient elements $\mathrm{Fe}$ and $\mathrm{Zn}$ as well as providing benefits through effects on plant growth, development and adaptability to adverse environments.

\subsection{Improvement of Fe and $\mathrm{Zn}$ uptake in plants in intercropping of chickpea/wheat by interspecific root interactions}

Malnutrition and micronutrient deficiencies, especially $\mathrm{Fe}$ and $\mathrm{Zn}$, can be prevalent in many chickpea- and wheatconsuming regions, even though chickpea and wheat seeds are good sources of essential mineral nutrients (Graham et al., 1999; Welch and Graham, 1999; Wang et al., 2003; Cakmak et al., 2004). However, in regions where wheat and chickpea are a significant component of the human diet, there appears to be considerable variation in the $\mathrm{Fe}$ and $\mathrm{Zn}$ concentrations present in the edible portions of the two crop species and their cultivars.

The ranges in $\mathrm{Fe}$ and $\mathrm{Zn}$ concentrations of wheat germplasm seeds grown in Mexico were $28.8-56.5 \mathrm{mg} \mathrm{kg}^{-1}$ 
Table III. Shoot and seed iron and zinc concentrations per dry mass of wheat and chickpea grown as monocropping and intercropping in field conditions (modified from Gunes et al., 2007).

\begin{tabular}{lcc}
\hline Cropping system & $\mathrm{Fe}\left(\mathrm{mg} \cdot \mathrm{kg}^{-1}\right)$ & $\mathrm{Zn}\left(\mathrm{mg} \cdot \mathrm{kg}^{-1}\right)$ \\
\hline Shoot & 28.69 & 5.71 \\
Wheat & 40.31 & 9.45 \\
Wheat intercropped & $* *$ & $* *$ \\
F test & 70.65 & 5.01 \\
Chickpea & 80.11 & 13.63 \\
Chickpea intercropped & $\mathrm{ns}$ & $* *$ \\
F test & & \\
Seed & 36.58 & 25.09 \\
Wheat & 46.13 & 27.10 \\
Wheat intercropped & $*$ & $\mathrm{~ns}$ \\
F test & 18.75 & 10.67 \\
Chickpea & 22.75 & 30.05 \\
Chickpea intercropped & $* *$ & $* *$ \\
F test & &
\end{tabular}

**: $P<0.01, *: P<0.05$ and ns: non-significant. Means within each column followed by different letters are significantly different by Duncan's multiple range test at $P=0.05$.

and $25.2-53.3 \mathrm{mg} \mathrm{kg}^{-1}$, respectively (Graham et al., 1999). Reported $\mathrm{Fe}$ and $\mathrm{Zn}$ concentrations $\left(\mathrm{mg} \mathrm{kg}^{-1}\right)$ of chickpea seeds for more than 20 cultivars varied between Fe 39-98 and Zn 25-35 (Williams and Singh, 1987). A breakthrough study was published in 2007 in which intercropping of wheat and chickpea improved the concentrations of $\mathrm{Fe}$ in wheat seeds, and $\mathrm{Fe}$ and $\mathrm{Zn}$ in chickpea seeds in the field experiment (Gunes et al., 2007). The concentrations of $\mathrm{Fe}$ and $\mathrm{Zn}$ in intercropped wheat shoots were significantly higher than in monocrop wheat. In chickpea, the Zn concentration was higher in intercropped chickpea than in the monocropped chickpea (Tab. III). Intercropping could overcome potential Fe and $\mathrm{Zn}$ nutrient deficiencies, particularly in harvested seeds.

In another chickpea/wheat study under a different $\mathrm{P}$ supply (Li et al., 2004), the Fe content in wheat shoots was significantly increased by the complete interspecies root interactions (intercropping) between wheat and chickpea, compared with treatments without the root contact (roots being separated by a solid root barrier, monocropping). The $\mathrm{Fe}$ content was increased by the free interspecies root interactions compared with the treatment with the root barrier and inorganic $\mathrm{P}$, suggesting mobilization of $\mathrm{Fe}$ from inorganic $\mathrm{FePO}_{4}$ by chickpea (Tab. IV). Zinc content in wheat and chickpea shoots supplied with inorganic $\mathrm{P}$ was increased by interspecies root interactions. Compared with the treatment with the root barrier, however, complete interspecies root interactions (no barrier) between two species increased $\mathrm{Zn}$ content in wheat shoots, but decreased $\mathrm{Zn}$ content in shoots of chickpea supplied with organic P (Tab. IV). This study indicated that the Fe and Zinc concentrations vary in response to both genetic and environmental factors. The results from this glasshouse study need to be verified in the field.

According to those studies, we propose that wheat/chickpea intercropping can potentially offer a more effective and feasible method both for increasing $\mathrm{Fe}$ and $\mathrm{Zn}$ in grain/seed of wheat and chickpea and producing human foods with a higher micromineral nutrient content than when the two species are grown as monocrops. However, considering the importance of different intercropping systems in nutrient acquisition and crop production processes, the management of intercropping would be the key to $\mathrm{Fe}$ and $\mathrm{Zn}$ biofortification.

\section{STRATEGIES FOR FE AND ZN UPTAKE IN PLANTS}

\subsection{Physiological responses to increase $\mathrm{Fe}$ and $\mathrm{Zn}$ uptake in plant species}

In general, plant species develop physiological responses to increase iron uptake under a Fe-deficient environment which are characterized as "Strategy I" and "Strategy II" systems (Curie and Briat, 2003; Hell and Stephan, 2003; Schmidt, 2003; Grotz and Guerinot, 2006). It is well known that peanut and maize have distinctly different response mechanisms to $\mathrm{Fe}$ deficiency stress. Peanut and chickpea are 'strategy I' plants, while maize and wheat belong to the 'strategy II' group. Specifically, peanut displays Strategy I mechanisms, under conditions of Fe deficiency, where reductase activity is increased and release of protons and reductants is enhanced from the roots. Furthermore, plants use the reduction strategy to mobilize iron from the rhizosphere and ferric chelate reductase activity has been shown to be the rate-limiting step for iron uptake (Guerinot, 2007). In calcareous soils, the high $\mathrm{pH}$ and large bicarbonate buffering capacity may render this strategy ineffective in the peanut due to decreased expression of a ferric chelate reductase (Bienfait, 1988; Guerinot, 2007). This strategy might not succeed even if Fe-efficient varieties of peanut were used in an attempt to overcome the iron chlorosis problem.

Strategy II plants are characterized by a higher Fe acquisition efficiency in soils with high $\mathrm{pH}$ and, in particular, high bicarbonate content through the excretion of phytosiderophores (PS) into the rhizosphere (Römheld and Marschner, 1986), and thus have a high resistance to Fe deficiency stress compared with strategy I plants. Graminaceous plant species respond to $\mathrm{Fe}$ and $\mathrm{Zn}$ deficiency by exudation of phytosiderophores to increase the availability of $\mathrm{Fe}$ and $\mathrm{Zn}$ and transport PS$\mathrm{Fe}(\mathrm{III})$ or PS-Zn from the rhizosphere to the root cell for uptake (Marschner et al., 1989; Cakmak et al., 1994). Grasses, which exude phytosiderophores in response to Fe deficiency, may also use this chelation strategy in order to obtain $\mathrm{Zn}$ from the soil. The mugineic acid family phytosiderophores (MAs) play a major role in iron $(\mathrm{Fe})$ acquisition, and may also contribute to the acquisition of $\mathrm{Zn}$ and other metal nutrients by graminaceous plants (Römheld, 1991; Welch, 1995; Wirén et al., 1996). Therefore, exudate phytosiderophores from gramineous species have important ecological significance in calcareous soil.

\subsection{Molecular regulation of $\mathrm{Fe}$ and $\mathrm{Zn}$ homeostasis in plants}

Significant progress on molecular aspects of $\mathrm{Fe}$ and $\mathrm{Zn}$ homeostasis in plants has been made in recent years in our 
Table IV. Iron and zinc content of wheat and chickpea grown with two P sources in monocropping and intercropping treatments (modified from Li et al., 2004).

\begin{tabular}{|c|c|c|c|c|c|}
\hline \multirow[b]{2}{*}{ Treatments } & & Wheat & \multicolumn{3}{|c|}{ Chickpea } \\
\hline & & $\begin{array}{c}\mathrm{Fe} \\
\left(\mu \mathrm{g} \mathrm{Fe} \operatorname{pot}^{-1}\right)\end{array}$ & 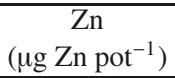 & $\begin{array}{c}\mathrm{Fe} \\
\left(\mu \mathrm{g} \mathrm{Fe} \text { pot }^{-1}\right)\end{array}$ & 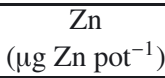 \\
\hline \multirow{2}{*}{$\begin{array}{l}\text { Organic P } \\
\text { (phytate) }\end{array}$} & Monocropping & $218 b$ & $209 \mathrm{~b}$ & $286 \mathrm{a}$ & $138 \mathrm{a}$ \\
\hline & Intercropping & $475 \mathrm{a}$ & $339 a$ & $193 b$ & $97 \mathrm{~b}$ \\
\hline \multirow{2}{*}{$\begin{array}{l}\text { Inorganic P } \\
\left(\mathrm{FePO}_{4}\right)\end{array}$} & Monocropping & $240 \mathrm{~b}$ & $327 b$ & $321 \mathrm{a}$ & $168 b$ \\
\hline & Intercropping & $340 \mathrm{a}$ & $440 \mathrm{a}$ & $343 a$ & $204 a b$ \\
\hline
\end{tabular}

Mean values of the three intercropping treatments with the same $P$ source followed by different letters $(\mathrm{a}, \mathrm{b})$ are significantly different $(P \leqslant 0.05)$.

understanding of how metals are obtained from the soil and distributed throughout the plant. For instance, in strategy I plants, Fe is first reduced on the root surface from ferric to ferrous ion by a plasma membrane-bound Fe(III) chelate reductase (FRO gene family) and subsequently translocated across the rhizodermal plasma membrane barrier by a high-affinity $\mathrm{Fe}$ (II) transporter such as the IRT gene family into the root cell (Varotto et al., 2002; Vert et al., 2002; Connolly et al., 2003; Mukherjee et al., 2005). Other Fe transporter genes, such as AtNRAMP3, AtNRAMP4 and AtVIT1, are all expressed in the vascular system of the roots and shoots, and the proteins that these genes encode appear to play a role in vacuolar Fe homeostasis (Thomine et al., 2003; Lanquar et al., 2005). Vacuolar Fe storage is also critical for seedling development that will ultimately aid to increase the chances of obtaining a nutrient-rich seed, benefiting both human health and agricultural productivity (Kim et al., 2006). Recent results confirmed that the FRD3-mediated efflux of citrate into the root vasculature is necessary for efficient Fe translocation; this process is important for the translocation of Fe to the leaves. FRD3 transports a small, organic iron-chelator that is necessary for the correct localization of Fe throughout the plant into the xylem (Durrett et al., 2007).

In strategy II plants, the first YS1 gene was identified from maize roots that could transport PS-Fe(III) from the rhizosphere (Curie et al., 2001). Recently, 18 YSL genes have been identified in rice, many of which are expressed in both the roots and the shoots (Koike et al., 2004). In fact, the YSL genes also play a role in Strategy I plants. The YSL family, consisting of eight members in Arabidopsis, has been implicated in the intercellular transport of Fe chelates, specifically Fe complexed into nicotianamine (NA), which regulates Fe and Zn homeostasis and plays a role in $\mathrm{Fe}$ and nicotianamine seed loading (Le Jean et al., 2005; Schaaf et al., 2005). A number of small, organic molecules have been implicated in metal ion homeostasis as metal ion ligands to facilitate uptake and transport of metal ions with low solubility and also as chelators implicated in sequestration for metal tolerance and efficient storage of metals in fruits and seeds (Haydon and Cobbett, 2007). A fuller understanding of the role of mugineic acid, nicotianamine, organic acids (citrate and malate), histidine and phytate as ligands for iron $(\mathrm{Fe})$, zinc $(\mathrm{Zn})$, copper $(\mathrm{Cu})$, manganese $(\mathrm{Mn})$ and nickel $(\mathrm{Ni})$ in plants could make a signifi- cant contribution to our understanding of metal homeostasis in plants.

Although the molecular mechanisms for $\mathrm{Zn}$ efficiency are not understood, it has been suggested that an increased secretion of phytosiderophores by Zn-efficient plants would be involved. Furthermore, several ZIP proteins have been characterized in the Strategy II rice plant, suggesting that this protein family plays a role in the grasses (Ramesh et al., 2003). Genetic engineering approaches have been applied to increasing plant tolerance to low-Zn soils. At present, knowledge of the genes controlling specific steps of the Zn network in soil-plant systems is still rudimentary, but increasing rapidly. Transformation and over-expression of known $\mathrm{Zn}$ transporters from Arabidopsis to barley (Hordeum vulgare cv. Golden Promise) can increase plant Zn uptake and seed Zn content (Ramesh et al., 2004). Recently, a NAC gene was identified in wheat, which can accelerate senescence and increase $\mathrm{Zn}$ and Fe remobilization from leaves to developing grains (Uauy et al., 2006). These results clearly show the contribution of molecular genetic tools to manipulating $\mathrm{Zn}$ and Fe efficiency in crops and the potential for enrichment of the food supply with $\mathrm{Zn}$ and Fe. Novel breeding strategies, combined with improved agronomy practice, have been developed based on these genetic findings. However, there is no information on how $\mathrm{Fe}$ and $\mathrm{Zn}$ nutrient content of seeds is affected by intercropping at a molecular level. The fact that many of the molecular and biochemical changes in response to Fe and $\mathrm{Zn}$ deficiency occur in synchrony suggests that genes involved in Fe or $\mathrm{Zn}$ uptake and translocation are co-ordinately expressed in intercropping. Therefore, systematic studies are needed to understand the molecular mechanisms of improvement of $\mathrm{Fe}$ and $\mathrm{Zn}$ content in the seeds of staple crops.

\section{THE MECHANISM OF IMPROVEMENT OF FE AND ZN UPTAKE IN INTERCROPPING}

\subsection{The potential role of phytosiderophores from graminaceous plants in improvement of Fe and $\mathrm{Zn}$ nutrition of dicot plants}

Cropping systems such as intercropping may have numerous advantages in terms of increasing availability of 


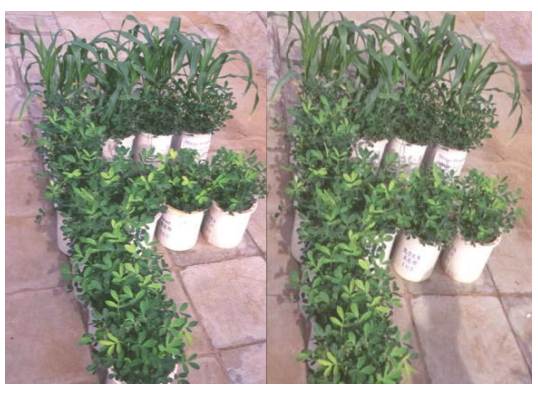

A

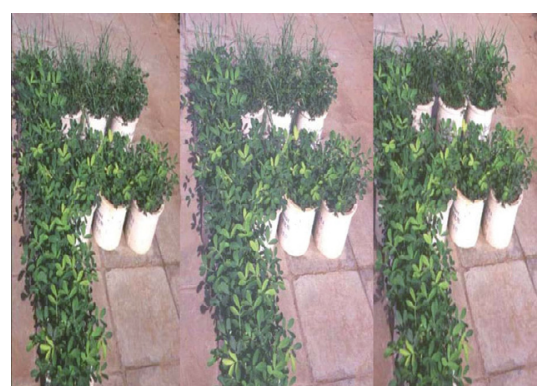

B

Figure 3. The effects of six cropping systems on iron deficiency chlorosis symptoms in the young leaves of peanut plants at 60 days growth. (A.) Peanut intercropping with two maize genotypes from left to right (danyu13, zhongdan2). (B.) Peanut intercropping with barley, oats or wheat from left to right. There are 7 pots of monocropped peanut and four pots of intercropped peanut and gramineous species in each picture.

micronutrients such as $\mathrm{Fe}$ and $\mathrm{Zn}$. In the peanut (Arachis hypogaea $\mathrm{L}$.)/maize (Zea mays L.) intercropping case, the excretion of phytosiderophores by maize into the rhizosphere plays an important role in improving Fe nutrition of peanut crops (Zuo et al., 2000). For strategy II plants, iron accumulation can be enhanced by the production of higher levels of phytosiderophores (Suzuki et al., 2006). There seems to be some cross-talk between the iron and zinc transport pathways because transgenic plants and mutants with overexpressed iron transporters also show increased zinc accumulation (Schaaf et al., 2005). Therefore, the possible reason for such differential effects on $\mathrm{Zn}$ concentrations of peanut plants caused by intercropping could be root exudates from gramineous species. Specifically, production and release of phytosiderophores from gramineous species may improve solubility of $\mathrm{Fe}$ and $\mathrm{Zn}$ by chelation, which helps plants obtain those essential elements from the soil (Rengel, 2002; Schmidt, 2003; Inal et al., 2007). In a study of peanut intercropping with different gramineous species, it was clearly shown that the incidence of chlorosis of peanut could be eliminated in intercropping with gramineous species such as two maize genotypes, barley, oats and wheat (Fig. 3). Moreover, there is a strong, positive correlation between the amounts of phytosiderophores and the resistance of plants to iron deficiency (Mori et al., 1987; Takagi et al., 1988; Zhang et al.,1990).

Generally speaking, the release rates of phytosiderophores of barley, oats and wheat are much higher than those of maize under solution culture conditions (the order is barley $>$ oats $>$ wheat $>$ maize). Plants that released more phytosiderophores positively correlated with improved growth in alkaline soils (Awad et al.,1994; Marschner and Römhed, 1994; Shen et al., 2002). The results indicated that the effect of improved iron nutrition of the peanut by the two genotypes of maize (danyu13 and zhongdan2) is similar to that of barley, oats and wheat in intercropping, and the iron content in shoots of peanut plants intercropped with maize was lower than that of peanut plants intercropped with barley, oats or wheat (Tab. V). In a greenhouse study, peanut intercropping with different gramineous species not only improved the iron nutrition of the peanut, but also enhanced zinc content in the peanut shoot. This suggests that the lower phytosiderophore
Table V. The effects of peanut intercropping with five gramineous plants on $\mathrm{Fe}$ and $\mathrm{Zn}$ contents ( $\mathrm{m} \mathrm{kg}^{-1}$.DW) in the shoot of peanut at 60 days' growth in the greenhouse experiment.

\begin{tabular}{lc}
\hline Treatments & Iron and zinc concentration in peanut \\
\hline & Fe content \\
Monocropping peanut & $190.5 \pm 13.1^{\mathrm{c}}$ \\
Peanut/maize(danyu13) & $313.6 \pm 16.5^{\mathrm{ab}}$ \\
Peanut/maize(zhongdan2) & $280.8 \pm 24.3^{\mathrm{b}}$ \\
Peanut/barley & $330.3 \pm 10.5^{\mathrm{a}}$ \\
peanut/oats & $345.7 \pm 24.0^{\mathrm{a}}$ \\
Peanut/wheat & $362.9 \pm 30.3^{\mathrm{a}}$ \\
& $\mathrm{Zn}$ content \\
Monocropped peanut & $109.8 \pm 3.1^{\mathrm{c}}$ \\
Peanut/maize(danyu13) & $124.4 \pm 7.2^{\mathrm{b}}$ \\
Peanut/maize(zhongdan2) & $119.9 \pm 4.3^{\mathrm{b}}$ \\
Peanut/barley & $121.0 \pm 6.9^{\mathrm{b}}$ \\
peanut/oats & $132.3 \pm 2.6^{\mathrm{a}}$ \\
Peanut/wheat & $122.3 \pm 10.3^{\mathrm{ab}}$
\end{tabular}

Columns with the same letter are not significantly different at 0.05 , using the LSD multiple range test.

levels produced by maize could be enough to improve iron nutrition of peanut in calcareous soil. It was not technically feasible to determine in the field the rates of synthesis and release of phytosiderophores of those gramineous species in different cropping setups, mostly because they cannot be recovered after release into the rhizosphere in soil conditions. It is difficult to answer directly the question of whether phytosiderophores play an important role in the improvement of iron nutrition in peanut, but there is some evidence to support the hypothesis.

\subsection{Ferric reductase capacity for improvement of $\mathrm{Fe}$ and $\mathrm{Zn}$ uptake in intercropped dicot plants}

For strategy I plants, the inducible activity of $\mathrm{Fe}^{3+}$ chelate reductase reduces $\mathrm{Fe}^{3+}$ to $\mathrm{Fe}^{2+}$, which is the rate-limiting step for $\mathrm{Fe}$ acquisition from soil (Ishimaru et al., 2007), so enhancing the $\mathrm{Fe}^{3+}$ chelate reductase activity of peanut plants renders those plants resistant to Fe deficiency. In a maize/peanut study 


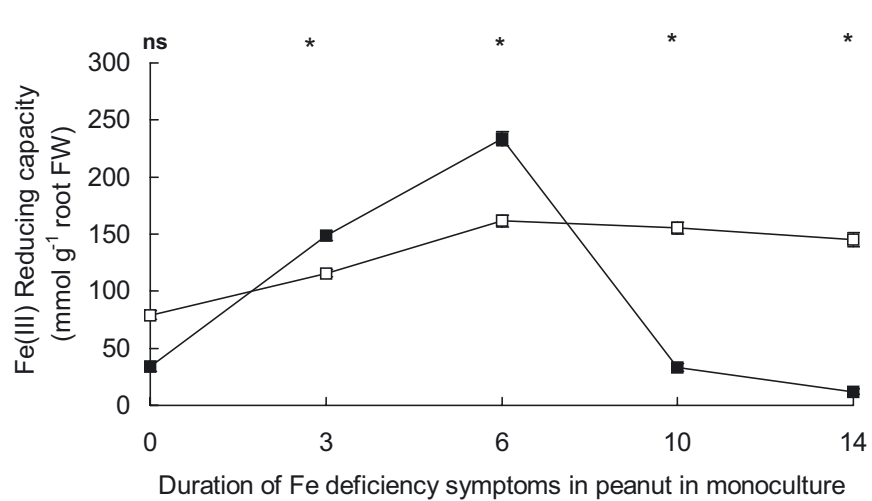

(days)

Figure 4. Reducing capacity of peanut roots in monocropping and intercropping during the period of Fe deficiency symptoms in peanut in monocropping. Significance of difference between monocropping and intercropping by paired t-test: $*, P<0.05$; ns, not significant. cropping type: $\square$, monocropping; $\square$, intercropping. Bars: standard error of the mean $(n=4)$.

in China (Zuo et al., 2003), the reducing capacity of peanut roots in monoculture increased in conjunction with the appearance of Fe deficiency chlorosis symptoms in young leaves. The maximum Fe(III)-reducing capacity of roots in monoculture occurred at 6 days and subsequently decreased rapidly. By the fourteenth day, when peanut showed severe Fe deficiency in monoculture, the reducing capacity of the roots was lower than that of peanut that had no Fe deficiency symptoms from the intercropped culture system. In contrast, the reducing capacity of peanut roots grown in intercropping with maize increased very slowly, and was greater than that of peanut roots from monoculture after the appearance of Fe deficiency chlorosis in monoculture at 10 days (Fig. 4). In another maize/peanut case in Turkey, the results also indicated that the root Fe(III)-reducing capacity of peanut was found to be significantly higher in intercropping $\left(0.56 \mathrm{mmol} \mathrm{Fe}^{-1} \mathrm{FW} \mathrm{h}^{-1}\right)$ than that of monocropped peanut $\left(0.29 \mathrm{mmol} \mathrm{Fe}^{-1} \mathrm{FW} \mathrm{h}^{-1}\right)$ (Inal et al., 2007). Those studies confirmed that maize/peanut intercropping could keep a higher ferric reduction capacity of peanut roots for a longer time period than that of monocropping, indicating that intercropping could enhance $\mathrm{Fe}^{3+}$ chelate reductase of peanut, which helps peanut plants tolerate Fe deficiency in calcareous soil.

Based on available research evidence, Figure 5 shows the possible mechanisms of improvement of iron and zinc nutrition of dicot plants in this review. In dicot plant/gramineous species intercropping systems in calcareous soil, the release of phytosiderophores by strategy II plants not only acquires Fe to meet their demand, but also improves Fe and $\mathrm{Zn}$ uptake of strategy I plants. Compared with monocropping dicot plants, one possible explanation is that gramineous species released phytosiderophores into the rhizosphere of dicot plants and helped to make much more phytosiderophore-Fe available to dicot plants in intercropping; however, there is no phytosiderophore-Fe available to dicot plants in monoculture. Although peanut does not produce phytosiderophores (PS) un-

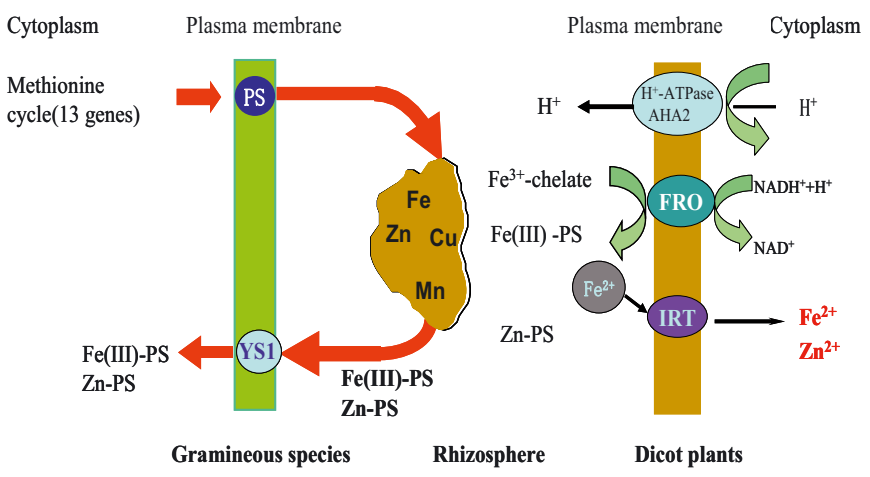

Figure 5. Summary of the possible molecular and physiological mechanisms of improvement in iron and zinc nutrition of dicot plants intercropped with gramineous species.

der Fe deficiency, phytosiderophore-Fe chelates from maize should exist in the rhizosphere of peanut intercropped with maize. For strategy I peanut plants, it has to reduce solubilized $\mathrm{Fe}(\mathrm{III})$ by a membrane-bound $\mathrm{Fe}$ (III) chelate reductase and subsequent transport of the resulting $\mathrm{Fe}(\mathrm{II})$ into the plant root cell by a Fe(II) transporter. Phytosiderophore-Fe is one of the $\mathrm{Fe}$ (III) states which are more easily reduced and taken up by dicots than other Fe(III) forms (Hopkins et al., 1992; Jolley and Brown, 1994), We infer from those studies that intercropping provides more phytosiderophore-Fe, which is easily reduced and absorbed by peanut. Furthermore, a higher ferric reduction capacity of dicot plant roots for a longer time period in intercropping may have assisted in the mobilization of sparingly soluble Fe(III) compounds from the rhizosphere so that the dicot plants remained green. A noteworthy advance in $\mathrm{Fe}$ and $\mathrm{Zn}$ research in plants is that there seems to be crosstalk between the iron and zinc transport pathways, because transgenic plants and mutants with overexpressed Fe(III) reductases and iron transporters also show increased zinc accumulation (Zhu et al., 2007). Those combined factors may thus have contributed to the improvement in Fe and $\mathrm{Zn}$ nutrition of dicot plants in intercropping with gramineous species.

\section{CONCLUSION}

Biofortification of iron and zinc content in plants is an emerging international research area of plant nutrition. Anemia as a result of iron deficiency afflicts more than two billion people worldwide, especially in developing countries including China (http://www.harvestPlus.org/iron.html). Biofortification of iron and zinc content and availability in plant foods could be an economical solution to this problem (Nestel et al., 2006; Yan et al., 2006). Enriching the nutrition contribution of staple crops through plant breeding, transgenic crops and mineral fertilization are significant tools in the fight against human malnutrition. Micronutrient-dense crop varieties are being developed using the best traditional breeding and modern biotechnology methods to achieve increases in nutrient concentrations. However, feasible and cost-effective approaches are needed, especially to reach the rural poor in developing 
countries. In this review, maize/peanut, chickpea/wheat and guava/sorghum or maize intercropping could overcome iron and zinc nutrient deficiencies, particularly in harvested seeds. The development of ecologically and economically viable strategies to prevent iron zinc deficiency represents the goal of the biofortification of crops.

The studies suggest that a rational intercropping system of nutrient-efficient species should be considered to prevent or mitigate iron and zinc deficiency of plants in agricultural practice. It will be one of a number of approaches to produce more biofortified crops. More researchers are becoming aware that increasing bioavailability of micronutrients in the edible parts of staple crops through agricultural management is a costeffective and sustainable way to alleviate micronutrient malnutrition. Although significant progress has been made in recent years in our understanding of how metals are obtained from the soil and distributed throughout the plant, there is still a lack of knowledge of how $\mathrm{Fe}$ and $\mathrm{Zn}$ micronutrients behave in intercropping systems of strategy I and strategy II plants. Substantial efforts are being made aimed at increasing plant $\mathrm{Fe}$ and $\mathrm{Zn}$ nutrient efficiency in intercropping at the molecular, cellular and whole-plant levels. This requires a multidisciplinary research approach, a willingness among scientists to communicate across disciplinary boundaries, and innovative funding strategies to support the research and ultimate dissemination of the biofortified seeds. Strategies for intercropping dicot plants and gramineous species could potentially contribute to iron and zinc biofortification in a more practical, effective and sustainable manner in developing countries.

Acknowledgements: We thank the National Natural Science Foundation of China (Grant No. 30570334), Changjiang Scholars and Innovative Research Team in the University (Grant No. IRT0511) for financial support, and Dr Rui Proenca for critically reading the manuscript.

\section{REFERENCES}

Awad F., Römheld V., Marschner H. (1994) Effect of root exudates on mobilization in the rhizosphere and uptake of iron by wheat plants, Plant Soil 165, 213-218.

Bienfait H.F. (1988) Mechanisms in Fe-efficiency reactions of higher plants, J. Plant Nutr. 11, 605-629.

Cakmak I. (2002) Plant nutrition research: priorities to meet human needs for food in sustainable ways, Plant Soil 247, 3-24.

Cakmak I., Gulut K.Y., Marschner H., Graham R.D. (1994) Effects of zinc and iron deficiency on phytosiderophore release in wheat genotypes differing in zinc efficiency, J. Plant Nutr. 17, 1-17.

Cakmak I., Torun B., Millet E., Feldmann M., Fahima T., Korol A., Nevo E., Braun H.J., Ozkan H. (2004) Triticum dicoccoides: an important genetic resource for increasing zinc and iron concentration in modern cultivated wheat, Soil Sci. Plant Nutr. 50, 1047-1054.

Connolly E.L., Campbell N., Grotz N.H., Prichard C.L., Guerinot M.L. (2003) Overexpression of the FRO2 ferric chelate reductase confers tolerance to growth on low iron and uncovers posttranscriptional control, Plant Physiol. 133, 1102-1110.

Curie C., Briat J.F. (2003) Iron transport and signaling in plants, Annu. Rev. Plant Biol. 54, 183-206.
Curie C., Panaviene Z., Loulergue C., Dellaporta S.L., Briat J.F., Walker E.L. (2001) Maize yellow stripe1 encodes a membrane protein directly involved in Fe(III) uptake, Nature 409, 346-349.

Durrett T.P., Gassmann W., Rogers E.E. (2007) The FRD3-mediated efflux of citrate into the root vasculature is necessary for efficient iron translocation, Plant Physiol. 144, 197-205.

Graham R.D., Senadhira D., Beebe S.E., Iglesias C. (1998) A strategy for breeding staple-food crops with high micronutrient density, Soil Sci. Plant Nutr. 43, 1153-1157.

Graham R.D., Senadhira D., Beebe S.E., Iglesias C., Monasterio I. (1999) Breeding for micronutrient density in edible portions of staple food crops: conventional approaches, Field Crops Res. 60, 57-80.

Graham R.D., Welch R.M. (2001) Addressing micronutrient malnutrition through enhancing the nutritional quality of staple foods: principles, perspectives and knowledge gaps, Adv. Agron. 70, 77-142.

Grotz N., Guerinot M.L. (2006) Molecular aspects of $\mathrm{Cu}, \mathrm{Fe}$ and $\mathrm{Zn}$ homeostasis in plants, Biochim. Biophys. Acta 1763, 595-608.

Guerinot M.L. (2007) It's elementary: Enhancing $\mathrm{Fe}^{3+}$ reduction improves rice yields, Proc. Natl Acad. Sci. USA 104, 7311-7312.

Gunes A., Inal A., Adak M.S., Alpaslan M., Bagci E.G., Erol T., Pilbeam D.J. (2007) Mineral nutrition of wheat, chickpea and lentil as affected by intercropped cropping and soil moisture, Nutr. Cycl. Agroecosyst. 78, 83-96.

Haydon M.J., Cobbett C.S. (2007) Transporters of ligands for essential metal ions in plants, New Phytol. 174, 499-506.

Hell R., Stephan U.W. (2003) Iron uptake, trafficking and homeostasis in plants, Planta 216, 541-551.

Hopkins B.G., Jolley V.D., Brown J.C. (1992) Plant utilization of iron solubilized by oat phytosiderophores, J. Plant Nutr. 15, 1599-1612.

Hopkins B.G., Jolley V.D., Brown J.C. (1992) Differential response of Feinefficient muskmelon, tomato, and soybean to phytosiderophore released by Coker 227 oat, J. Plant Nutr. 15, 35-48.

Inal A., Gunes A. (2007) Interspecific root interactions and rhizosphere effects on salt ions and nutrient uptake between intercropped grown peanut/maize and peanut/barley in original saline-sodic-boron toxic soil, J. Plant Physiol. 1-14.

Inal A., Gunes A., Zhang F.S., Cakmak I. (2007) Peanut/maize intercropping induced changes in rhizosphere and nutrient concentrations in shoots, Plant Physiol. Bioch. 45, 350-356.

Ishimaru Y., Kim S., Tsukamoto T., Oki H., Kobayashi T., Watanabe S., Matsuhashi S., Takahashi M., Nakanishi H., Mori S., Nishizawa N.K. (2007) Mutational reconstructed ferric chelate reductase confers enhanced tolerance in rice to iron deficiency in calcareous soil, Proc. Natl Acad. Sci. USA 104, 7373-7378.

Jeong J., Guerinot M.L. (2008) Biofortified and bioavailable: The gold standard for plant-based diets, PNAS 6, 1777-1778.

Jolley V.D., Brown J.C. (1994) Genetically Controlled Uptake and Use of Iron by Plants In Biochemistry of Micronutrients in the Rhizosphere, in: Manthey J.A., Crowley D.E., Luster D.G. (Eds.), CRC Press, Boca Raton, LA, pp. 251-266.

Kamal K., Hagagg L., Awad F. (2000) Improved Fe and Zn acquisitionby guava seedlings grown in calcareous soils intercropped with graminaceous species, J. Plant Nutr. 23, 2071-2080.

Kim S.A., Punshon T., Lanzirotti A., Li L., Alonso J.M., Ecker J.R., Kaplan J., Guerinot M.L. (2006) Localization of iron in Arabidopsis seed requires the vacuolar membrane transporter VIT1, Science 314, 1295-1298.

Koike S., Inoue H., Mizuno D., Takahashi M., Nakanishi H., Mori S. Nishizawa N.K. (2004) OsYSL2 is a rice metal-nicotianamine transporter that is regulated by iron and expressed in the phloem, Plant J. 39, 415-424. 
Lanquar V., Lelièvre F., Bolte S., Hamès C., Alcon C., Neumann D., Vansuyt G., Curie C., Schröder A., Krämer U., Barbier-Brygoo H., Thomine S. (2005) Mobilization of vacuolar iron by AtNRAMP3 and AtNRAMP4 is essential for seed germination on low iron, EMBO J. 24, 4041-4051.

Le Jean M., Schikora A., Mari S., Briat J.F., Curie C. (2005) A lossof-function mutation in AtYSL1 reveals its role in iron and nicotianamine seed loading, Plant J. 44, 769-782.

Li L., Li S.M., Sun J.H., Zhou L.L., Bao X.G., Zhang H.G., Zhang F.S. (2007) Diversity enhances agricultural productivity via rhizosphere phosphorus facilitation on phosphorus-deficient soils, Proc. Natl Acad. Sci. USA 104, 11192-11196.

Li L., Tang C., Rengel Z., Zhang F.S. (2004) Calcium, magnesium and microelement uptake as affected by phosphorus sources and interspecific root interactions between wheat and chickpea, Plant Soil 261, 29-37.

Li L., Yang S.C., Li X.L., Zhang F.S., Christie P. (1999) Interspecific complementary and competitive interaction between intercropped maize and faba bean, Plant Soil 212, 105-114.

Liu X.H. (1994) The Farming Systems, China Agric Univ Press, Beijing.

Marschner H., Römheld V. (1994) Strategies of plants for acquisition of iron, Plant Soil 165, 261-274.

Marschner H., Treeby M., Römheld V. (1989) Role of root-induced changes in the rhizosphere for iron acquisition in higher plants, $\mathrm{Z}$. Pflanzenernaehr Bodenkd. 152, 197-204.

Mayer J.E., Pfeiffer W.H., Beyer P. (2008). Biofortified crops to alleviate micronutrient malnutrition, Curr. Opin. Plant Biol. 11, 166-170.

Mori S., Nishizawa N., Kawai S., Sata Y., Takahi S. (1987) Dynamic state of mugineic acid and analogous PS in Fe-deficiency barley, J. Plant Nutr. 10, 1003-1011.

Mukherjee I., Campbell N.H., Ash J.S., Connolly E.L. (2005) Expression profiling of the Arabidopsis ferric chelate reductase (FRO) gene family reveals differential regulation by iron and copper, Planta 223, 1178-1190.

Nestel P., Bouis H.E., Meenakshi J.V., Pfeiffer W. (2006) Symposium: Food Fortification in Developing Countries, J. Nutr. 136, 1064 1067.

Prasad A.S. (2003) Zinc deficiency has been known for 40 years but ignored by global health organizations. Brit. Med. J. 356, 422-424.

Ramesh S.A., Choimes S., Schachtman D.P. (2004) Over-expression of an Arabidopsis zinc transporter in Hordeum vulgare increases short-term zinc uptake after zinc deprivation and seed zinc content, Plant Mol. Biol. 54, 373-385.

Ramesh S.A., Shin R., Eide D.J., Schachtman D.P. (2003) Differential metal selectivity and gene expression of two zinc transporters from rice, Plant Physiol. 133, 126-134.

Rengel Z. (2002) Genetic control of root exudation, Plant Soil 245, 5970.

Römheld V. (1991) The role of phytosiderophores in acquisition of iron and other micronutrients in graminaceous species: An ecological approach, Plant Soil 130, 127-134.

Römheld V., Marschner H. (1986) Evidence for a specific uptake system for iron phytosiderophores in roots of grasses, Plant Physiol. 80, 175-180.

Schaaf G., Schikora A., Häberle J., Vert G., Ludewig U., Briat J.F., Curie C., von Wirén N. (2005) A putative function for the Arabidopsis Fe-Phytosiderophore transporter homolog AtYSL2 in Fe and Zn homeostasis, Plant Cell Physiol. 46, 762-774.

Schmidt W. (2003) Iron solutions: acquisition strategies and signaling pathways in plants, Trends Plant Sci. 8, 188-193.
Shen J., Zhang F., Chen Q., Rengel Z., Tang C., Song C. (2002) Genotypic difference in seed iron content and early responses to iron deficiency in wheat, J. Plant Nutr. 25, 1631-1643.

Suzuki M., Takahashi M., Tsukamoto T., Watanabe S., Matsuhashi S., Yazaki J., Kishimoto N., Kikuchi S., Nakanishi H., Mori S., Nishizawa N.K. (2006) Biosynthesis and secretion of mugineic acid family phytosiderophores in zinc-deficient barley, Plant J. 48, 85-97.

Takagi S., Kamei S., Yu M.H. (1988) Efficiency of iron extraction from soil by mugineic acid family phytosiderophores, J. Plant Nutr. 11, 643-651.

Thomine S., Lelièvre F., Debarbieux E., Schroeder J.I., Barbier-Bygoo H. (2003) AtNRAMP3, a multispecific vacuolar metal transporter involved in plant responses to iron deficiency, Plant J. 34, 685-695.

Uauy C., Distelfeld A., Fahima T., Blechl A., Dubcovsky J. (2006) A NAC gene regulating senescence improves grain protein, zinc, and iron content in wheat, Science 314, 1298-1301.

Vandermeer J. (1989) The Ecology of Intercropping, Cambridge Univ. Press, Cambridge.

Varotto C., Maiwald D., Pesaresi P., Jahns P., Salamini F., Leister D. (2002) The metal ion transporter IRT1 is necessary for iron homeostasis and efficient photosynthesis in Arabidopsis thaliana, Plant J. 31, 589-599.

Vert G., Grotz N., Dédaldéchamp F., Gaymard F., Guerinot M.L., Briat J.F., Curie C. (2002) IRT1, an Arabidopsis transporter essential for iron uptake from the soil and for plant growth, Plant Cell 14, 12231233 .

Wang T.L., Domoney C., Hedley C.L., Casey R., Grusak M.A. (2003) Can we improve nutritional quality of legume seeds? Plant Physiol. 131, 886-891.

Welch R.M. (1995) Micronutrient nutrition of plants, Crit. Rev. Plant Sci. $14,49-82$

Welch R.M., Graham R.D. (1999) A new paradigm for world agriculture: meeting human needs - productive, sustainable, nutritious, Field Crops Res. 60, 1-10.

WHO (2007) Micronutrient deficiency: iron deficiency anaemia. Geneva: WHO, available from http://www.who.int/nutrition/topics/ida/>.

Williams P.C., Singh U. (1987) Nutritional quality and evaluation of quality in breeding programs, in: Saxena M.C., Singh K.B. (Eds.), The Chickpea, Cab Int, Wallingford, pp. 329-356.

Wirén N.V., Marschner H., Römheld V. (1996) Roots of iron-efficient maize also absorb phytosiderophore-chelated zinc, Plant Physiol. $111,1119-1125$.

Yan X.L., Wu P., Ling H.Q., Xu G.H., Xu F.S., Zhang Q.F. (2006) Plant Nutriomics in China: An Overview, Ann Bot-London 98, 473-482.

Zhang F., Treeby M., Römheld V., Marschner H. (1990) Mobilization of iron by phytosiderophores as affected by other micronutrients, Plant Soil 130,173-178.

Zhang F.S., Li L. (2003) Using competitive and facilitative interactions in intercropping systems enhances crop productivity and nutrient-use efficiency, Plant Soil 248, 305-312.

Zhu C.F., Naqvi S., Gomez-Galera S., Pelacho A.M., Teresa Capell T., Christou P. (2007). Transgenic Transgenic strategies for the nutritional enhancement of plants, Trends Plant Sci. 12, 1360-1385.

Zuo Y.M., Zhang F.S., Li X.L., Cao Y.P. (2000) Studies on the improvement in iron nutrition of peanut by intercropping maize on a calcareous soil, Plant Soil 220, 13-25.

Zuo Y.M., Li X.L., Zhang F.S., Christie P. (2003) Iron nutrition of peanut enhanced by intercropped cropping with maize: role of root morphology and rhizosphere microflora, J. Plant Nutr. 10; 11, 20932110. Website: http://www.harvestPlus.org/iron.html. 